DOI 10.18551/rjoas.2019-08.10

\title{
REFORMULATION OF BUSINESS STRATEGY TO INCREASE CREDIT GUARANTEE IN PT. JAMKRIDA BALI MANDARA
}

\author{
Putra I Ketut Indra Satya Dharma*, Setiawan Putu Yudi \\ Faculty of Economics and Business, University of Udayana, Bali, Indonesia \\ *E-mail: indraputra33@gmail.com
}

\begin{abstract}
PT. Jamkrida Bali Mandara is a Credit Guarantee Institution in Bali, Indonesia. Reformulating business strategies is needed as a part of their strategies to win business competition and to achieve the goal of company. The objectives of this study are: identifying its internal strengths and weaknesses, as well as its external opportunities and threats; finding out the accurate business model and strategy of PT. Jamkrida Bali Mandara to grow and win the business. The analytical method used is descriptive qualitative analysis method, mapping current business models, SWOT analysis of current business models and designing new business model innovations. Data collection methods used is thorough interviews and observations by determining the population and a sample of 20 people. SWOT analysis with IFAS matrix shows result of 3.116 and EFAS matrix shows of 3.160 which are in Quadrant I in IE Matrix. So that market penetration and development and product development are strategies that must be done to increase credit guarantee. There are several policies in the future that need attention for the management of PT. Jamkrida Bali Mandara as follows: a) Market Development, b) Product Development, c) Automated business process using information and Tecnology, and d) Business Partner Development.
\end{abstract}

\section{KEY WORDS}

Business model, SWOT analysis, reformulation, business strategy.

The Credit Guarantee Institution has becoming more important in being part of Indonesian government policies to encourage the growth of enterpreneurship in the micro, small and medium enterprises (SMEs). Furthermore, PT. Jamkrida Bali Mandara has significant and important function in encouraging the growth of economic in Bali.

Hence, problems and issues of SMEs to acces financial institution are defined by two side of party: 1) Complement Management of Financial Institution, 2) Ability and visibility business of SMEs. In this condition, the important of fuction of PT. Jamkrida Bali Mandara-which is to connect both parties--will be more significant (Puspayoga, 2015). Credit guarantee Institution is solution to gain credit for SMEs expecially those with inadequate collaterral or even without collateral or track record to gain acces to credit, and complement the Goverments efforts promoting and developing business sector which are keys to spurring economy (Anwar, 2015).

The economics situation of Indonesia and Bali has stabilized but Bali has better situation than Indonesia. This situation stimulated the growth of volume of credit as the potential for business of PT. Jamkrida Bali Mandara.

Table 1 - Credit Composition According to its use based on Bank and Non-Bank Financial Institutions, 2011 - 2017 (Rp.miliar)

\begin{tabular}{cccccc}
\hline Type of Credit & \multicolumn{2}{c}{ Bank and Non Bank } & \multicolumn{2}{c}{ Total } \\
\hline Productive Credit & BPD & BPR & Koperasi & LPD & 97,080 \\
Non-productive loans & 33,003 & 30,051 & 18,921 & 15,105 & 127,146 \\
\hline Total Credit & 51,728 & 18,000 & 22,170 & 35,248 & 224,226 \\
\hline
\end{tabular}

Source: OJK Regional Office 8 Bali and Nusa Tenggara, Provincial Cooperative Office Bali and LPD LP (Data Processed). 
Lowest achievement of credit guarantee that covered (risk of credit) by JBM only 2,6\% or IDR 5,7 billion from total volume credit distribution IDR 224,2 billion. Knowing the biggest potential size of credit which hasn't been covered by JBM, it's required to determine the causes. For achieving its goal to win the business, JBM must reformulate the right business strategy and restructure business model.

Business model described as how a company make an added value in job market, including combination of product, services, image, and distribution and human asset and infrastructure. Also, the concept business model is between between input that used by company for gain economy output (Afuah, 2004; Davenport et al. 2006; Osterwalder and Pigneur, 2004). Business model defined as architecture for product, services, people and regulation, financial benefit for people who were involved and the source of incomes (Timmers, 1998). The point of Business Model is a chain of company value (Porter, 1985). This model design for use as a tool for take advantage from oppurtunities (Makinen and Seppanen, 2007). Cavalcante et al. (2011) said; before doing analysis to modify business model in long term, it's needed to consider some persepective to business model, so that the modification process can turn out to be succesful. There are 4 types of modification: 1) Business Model Creation, creating new business model depending on company conditions 2) Business Model Extension, modifying the established business model 3) Business Model Revision, revising the business model that still working 4) Business Model Termination, threat business model by termin.

Persisting Problems:

- How do we identify strengths and weaknesses to anticipate oppurtunities and threats? Also how do we plan the strategy and business model formula for developing the company in the future in related to increase the market share of PT. Jamkrida Bali Mandara?

The goals of this study are to identify business model of Pt. Jamkrida Bali Mandara, SWOT analysis and innovation for designing new business model through comparation with business model based on SWOT Analysis. Business model used is based on Canvas Business Model which focused on the improvement of business model for increasing the performance of company and product. The framework of this research can be seen in Figure 1.

\section{LITERATURE REVIEW}

To understand the definition of business model, this study uses various terminology of business model issued by academics (Table 1).

The research of business model by Magfirah et al. (2012), Priandita and Toha (2013), Saksono (2013), Karsen (2013), and Danica (2012) explain; to design innovation of business model in the beginning needs to be analysed by establishing business model of the company. After understanding the scheme of business model or product, then SWOT analysis is conducted to find out the components of weakest and strongest element of the product or a company. After that, we can build the new business model. According to Fasha and Larso (2012), designing new business model in a company is needed to optimize the resources and to combine with opportunity to earn a good value proportion.

To create a Business Model Canvas as suggested, it is needed to identify the business policy strategies based on SWOT analysis. This analysis describes how the business strategy collaborated with internal factor such as strength and weakness and external variable including opportunities and threats as the impact of collaborated of strength (S) with opportunities $(\mathrm{O})$, strength $(\mathrm{S})$ with threats $(\mathrm{T})$, weaknesses $(\mathrm{W})$ with opportunities $(\mathrm{O})$, and weaknesses (W) with threats $(T)$. This model still related to nine elements that mention before.

This research used descriptive method with approach of Case Study and qualitative method. The data collected from 2018, composed by 2 kinds of data, Primary and Secondary. Primary Data consist of information, opinion, policies, judgment originated from internal management and partners of PT. Jamkrida Bali Mandara with sample population 20 
respondents. The information collected related to problems company face, condition of human resources, daily operation and Oppurtunities and Threats PT. Jamkrida Bali Mandara. Secondary data collected through Literature Study related to condition of PT. Jamkrida Bali Mandara in general collected from document and internal report of PT. Jamkrida Bali Mandara.

Table 2 - Literature Review Analysis

\begin{tabular}{|c|c|}
\hline Author & Definition Business Model Canvas \\
\hline Giorgetti (1998) & $\begin{array}{l}\text { Refence model as a basis for a new type of system that have some } \\
\text { advantages rather than before. }\end{array}$ \\
\hline Timmer (1998) & $\begin{array}{l}\text { Architech of product, services and flow of information including } \\
\text { description from various business people and their experiences, } \\
\text { description of potential benefit fand resource of business incomes. }\end{array}$ \\
\hline Tapscott et al. (2000) & $\begin{array}{l}\text { Discussing business innovation model refer to (b-webs) to redesign new } \\
\text { value preposition, transformation of competition regulations, mobilized } \\
\text { people and other resources to increase performance. }\end{array}$ \\
\hline Kraemer et al. (2000) & $\begin{array}{l}\text { No specific definition terminology of business model but it is identified by } \\
4 \text { building block such a direct sales, direct customer relationships, } \\
\text { customer segmentation for sales and service, build- to- order } \\
\text { production. }\end{array}$ \\
\hline Rappa (2000) & $\begin{array}{l}\text { A method that used by company to run the business so the business } \\
\text { can survive. }\end{array}$ \\
\hline Christensen (2001) & $\begin{array}{l}\text { As a source of competitive superiority of organization that it can be } \\
\text { diferrent company positioning even in the same type of business. }\end{array}$ \\
\hline $\begin{array}{l}\text { Al-Debei et al., 2008a; Amit and Zott, 2001; } \\
\text { Casadesus-Masanell and Ricart, 2010; Osterwalder, } \\
\text { 2004; Rajala and Westerlund, 2005; Tikkanen et al., } \\
\text { 2005). Casadesus-Masanell and Ricart (2010) }\end{array}$ & $\begin{array}{l}\text { Difference Concept: business model is direct result from strategy while } \\
\text { the strategy its independence. }\end{array}$ \\
\hline Zott et al. (2010) & $\begin{array}{l}\text { As a tool to anticipate } 3 \text { phenomenons such as: 1) e-business and IT 2) } \\
\text { strategic issue, create value, competitive superiority and company } \\
\text { performance; 3) innovation and technology management }\end{array}$ \\
\hline Osterwalder and Pigneur (2010) & $\begin{array}{l}\text { Described as base of mindset on how the organisation creates, gives } \\
\text { and designs the value. }\end{array}$ \\
\hline Teece (2010) & $\begin{array}{l}\text { Determine how the company give the added value, persuade customer } \\
\text { to pay added value and change the payment becoming a benefit }\end{array}$ \\
\hline Wheelen and Hunger (2010) & $\begin{array}{l}\text { A method that used by company to earn the money in the business } \\
\text { environment where the company located }\end{array}$ \\
\hline Cavalcante, et al (2011) & $\begin{array}{l}\text { Flexibility, but only for added or reduce without endangering or chaning } \\
\text { the established process of the core business. }\end{array}$ \\
\hline Bertels et al. (2015) & $\begin{array}{l}\text { Divided by nine separated block that can give an integrated visual } \\
\text { representation. The nine blocks related each other, also crelated to our } \\
\text { definition of business model. The nine blocks are; Key Resources, Key } \\
\text { Activity), Key Partner, Value Proposition, Cost Revenue, Customer } \\
\text { Relationship, Customer Segmentation, Distribution Channel. }\end{array}$ \\
\hline Dudin et al. (2015) & $\begin{array}{l}\text { A modern tool for strategic management that can be used to optimise } \\
\text { financial aspect from daily activity by economy entity }\end{array}$ \\
\hline
\end{tabular}

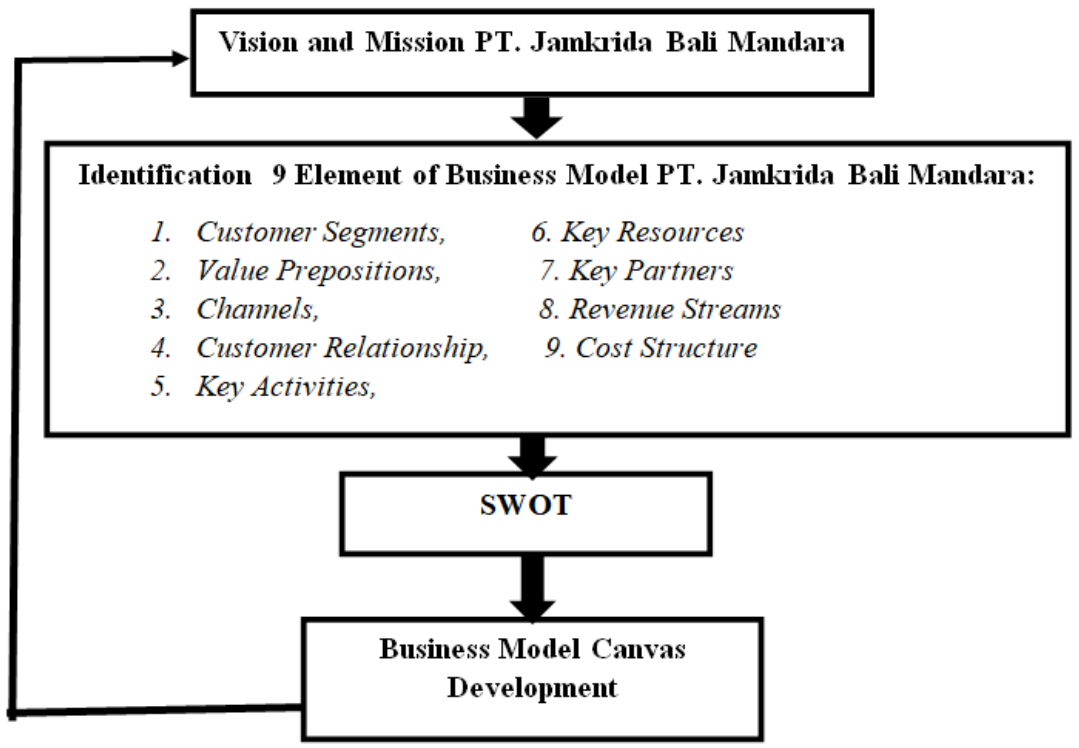

Figure 1 - Research Framework 


\section{METHODS OF RESEARCH}

Descriptive Data is a statement from the respondents and their behavior that observed regarding to object of research, then it's analyzed with quantitative method, and the result is used to be a guideline to design the innovation business model based on business model that used it at the times. The guidelines Business Model is a Business canvas which originally declared by Osterwalder and Pigneur (2010). Business Model used as a structural based for a company to interaction with customers, partnerts and vendors (Zott and Amit, 2007). To design the inovation business model to encourage and increase credit guarantee, there are 3 steps of the method which are; (1) Vision and Mission Analysis, (2 Mapping hence business model (3) SWOT analysis to hence business model. (4) Designing New Business Model

On mapping business model at the times, first we need to define and fulfill customer segments. Element of customer segments defines varioust group of people or organization. This step is achieved to understanding customers' satisfaction and the services that is critical from this business model. Next step is fulfilling value propositions that are a benefit that offers to customer segmentations. After that, channels will describe how the company communicate to meet with customer needs to give a value propositions, distribution, and sales revenue. Customer relationships are the way to organize, interact, and build customer trust. If focusing customer segments do good value propositions will have good impact, also if channels and customer relationships build to be better, revenue streams will be earned from every transaction from customer. Internal element of company is a key resources, key activities, key partnerships which can keep a company to be more efficient. Efficiency is needed to control the cost structure.

\section{RESULTS AND DISCUSSION}

PT. Jamkrida Bali Mandara) is Indonesian state owned by government of Bali Province (BUMD), which specializing in Credit Guarantee for SMEs. On operating the business, the guidelines refer to Vision and Mision of Company. Vision of PT. Jamkrida Bali Mandara said to be; "Becoming a Credit Guarantee Company which is competitive, trusted and suistainable to support the growth of SMEs business sector, as apart of a government partner to encourage the growth of Balinese economy. Mission of PT. Jamkrida Bali Mandara are; a) Operate business of credit guarantee and management consultant for SMEs in order to strengthening SMEs, b) Increasing professionalism to operate a company becoming profitable and growth, and best services to customer, partnerts, public, and shareholders, c) Proactive to all kind of changes and accomodating with stakeholders.

First step of this research is analysis current business model in PT, jamkrida Bali Mandara, and then mapping to Business Model Canvas (BMC):

Customers Segment of PT. Jamkrida Bali Mandara (JBM) is a partners who have economic value or given critical contribution to Cash Inflow. There are 402 partnerts such as; Bank BPD Bali, Bank BPR Bali, LPD Bali, Kospin, Bumdes, Ventura Capital, Construction Enterpreneur.

Value Proposition described as combination between product and services of company to create a value for customers. The Core Business of JBM is guaranteeing a credit issued from partnerts to debitur. Gurantee of risk of credit and Coverage of unfullfill collateral of debitur. There are various type of credit guarantee product from JBM: a) Credit Guarantee such as: Multipurpose Credit Guarante, Construction and Credit Procurement, Credit Linkage, Credit for SMEs, b) Non-Credit Guarantee such as Surety Bond, Bid Bond, Performance Bond, Advance Payment Bond, Maintenance Bond and issuing Bank Guarantee/Contra Bank Guarantee; Contra Bank Guarantee Surety Bond, Bid Bond, Performance Bond, Advance Payment Bond, Maintenance Bond.

Customer Relationship is how the company build the relationship to target customers to provide better services. The former relationship transforms through a) Customer Gathering b) Reciprocal Business. 
Channel is a tool or media to communicate with customers to give added value for brand identity of company. For positioning brand and value of company JBM has channels as company comittments to grab and build the communication with customers such as online channels: website www.jamkridabali.co.id, and offline channel: Credit Guarantee Officer (CGO), this channels give a proper information and monitoring product and services regarding customer satisfaction

Revenue earned from every segment of customer and also described as how the company earn the income. Sources of incomes JBM: a) Fee from guarantee credit and non credit, b) Re-Insurance Commissions from Broker Agent and Re-Insurance from Sharing Risk, c) Interest of Deposito, Fee giro and Savings, d) Coupon Rate of obligation and mutual funds, e) Subrogated claim payment from JBM to partners, f) Others incomes, such as incidental incomes likes sponsorship fee.

Key Resources are assets or important source owned by company such as verified assets, infrastructure, money, people, and company culture/value or given by Key Partners. According to Osterwalder and Pigneur (2010), Resources might possible a company to make and offering value proposition, grab the market, maintain customer relationship, and earn revenue. Key resources can be different, depends on type of business model. There are 4 categories on key resources of JBM: a) Verified Asset, Building of office PT. Jamkrida Bali Mandara, b) Legal Formal, as a company stated owned by government, c) Human Resources, JBM team to operate daily business JBM divide by some department: 1) Department of Credit; Guarantee, Analysis, Administration, Claim and Subrogation, Risk Management and Credit Guarantee Officer, 2) Non Credit Department; Administration, Agent, 3) Department of Finance and Accountant, 4) Department Legal, 5) Department Human Resources, General Affairs and IT, 6) Department Financial, on this department. d) Financial, JBM depend on capital equity from shareholders. The volume of equity will impact its ability and capacity of guarantee (Gearing Ratio JBM is only 40 times of capital). From Capital of IDR 130 billion, JBM's ability to guarantee the credit is only IDR 5,2 billion. From capacity of JBM only 20 x productive business sector guarantee or IDR 2,6 billion and $20 \mathrm{x}$ guarantee for non productive sector.

Key Activities Is the main activity that must be carried out by companies / business entities so that the business model can run well, among others, as follows: 1) Carrying out business activities through the provision of credit guarantee services by paying payments financially guaranteed to the guarantee recipient if guaranteed not to be able to fulfill their obligations based on the agreed agreement. 2) In addition to conducting business activities as mentioned above, the Company may conduct other business activities, namely: a) Guarantee loans channeled by cooperatives to its members; b) Guarantee the procurement of surety bonds; c) Conduct bank guarantee guarantees (counter bank guarantees); d) Assuring domestic documented letters of credit (SKBDN); e) Conducting custom bonds; $f$ ) Providing management consulting services related to guarantee business activities; g) Conduct other guarantees after obtaining Minister's approval.

Key Partnership Describes relationships with third parties / is a key partner / partner that is important so that the business model can run smoothly. 1) Strategic alliances between non-competitors are to conduct Co Guarantee with fellow Regional Credit Guarantee Companies in various Provinces in Indonesia, which aim to maximize credit guarantee capabilities. 2) Coopetition: strategic partnership between competitors is a collaboration carried out to do Sharing Risk with the Re Insurance mechanism.

Cost Structure is the composition of costs to operate an organization in realizing the value porous is given to customers. The cost structure is as follows: a) Expenses of $\operatorname{Re}$ Insurance; b) Guarantee Operating Expenses; c) Claim Reserves; d) Operational Expenses; e) HR Expenses; f) Office and General Administration Expenses; g) Depreciation Expenses.

Business Model Canvas is made before the SWOT Analysis conducted. It is a general description of hence company condition. The description shows on that model could be used to make a business policy or a new business strategy in the future. The Description that can get from that business model describe on 9 element model. Business Model Canvas PT. Jamkrida Bali Mandara before define SWOT strategy show as below: 
Table 3 - SWOT Strategy

\begin{tabular}{|c|c|c|c|c|}
\hline Key Partners & Key Activities & \multirow{2}{*}{$\begin{array}{l}\text { Value } \\
\text { Proposition }\end{array}$} & \multirow{2}{*}{$\begin{array}{l}\text { Customer } \\
\text { Relationships }\end{array}$} & Customer Segments \\
\hline \multirow{6}{*}{$\begin{array}{l}\text { Co Guarantee } \\
\text { Re Insurance }\end{array}$} & & & & \multirow{6}{*}{$\begin{array}{l}\text { BPD Bali } \\
\text { BPR } \\
\text { LPD } \\
\text { Koperasi Simpan Pinjam } \\
\text { Bumdes } \\
\text { LPDB } \\
\text { Ventura Capital } \\
\text { Conventional Banks }\end{array}$} \\
\hline & $\begin{array}{l}\text { Credit Guarantee } \\
\text { Services and others }\end{array}$ & \multirow{5}{*}{$\begin{array}{l}\text { Credit } \\
\text { Guarantee } \\
\text { Guarantee } \\
\text { Non Credit }\end{array}$} & Customer Gathering & \\
\hline & guarantee & & & \\
\hline & & & & \\
\hline & Key Resources & & Channels & \\
\hline & $\begin{array}{l}\text { Building, a state owned } \\
\text { company on credit } \\
\text { guarantee with a proper } \\
\text { licence }\end{array}$ & & $\begin{array}{l}\text { Web Site, E-mail, Credit Guarantee } \\
\text { Officer }\end{array}$ & \\
\hline \multicolumn{3}{|l|}{ Cost Structure } & \multicolumn{2}{|l|}{ Revenue Streams } \\
\hline \multicolumn{3}{|c|}{$\begin{array}{l}\text { Cost Re Insurance, Guarantee Operation, Reverse Claim, } \\
\text { Daily Operation, Human Resources, Admisitration office } \\
\text { and General affairs and Depreciation. }\end{array}$} & \multicolumn{2}{|c|}{$\begin{array}{l}\text { Incomes Fee Guarante services, Fee Guarantee, Re Insurance } \\
\text { Commissions, Interest deposito, fee giro and savings, Coupon } \\
\text { Rate for obligation and others. }\end{array}$} \\
\hline
\end{tabular}

To make a corporate strategy, we have to identify internal factor which is consist of strength and weakness through analyze using a IFAS and external variable; opportunity and treath with analyze using a matrics EFAS, to Business Model Canvas as below:

Table 4 - Business Model Canvas

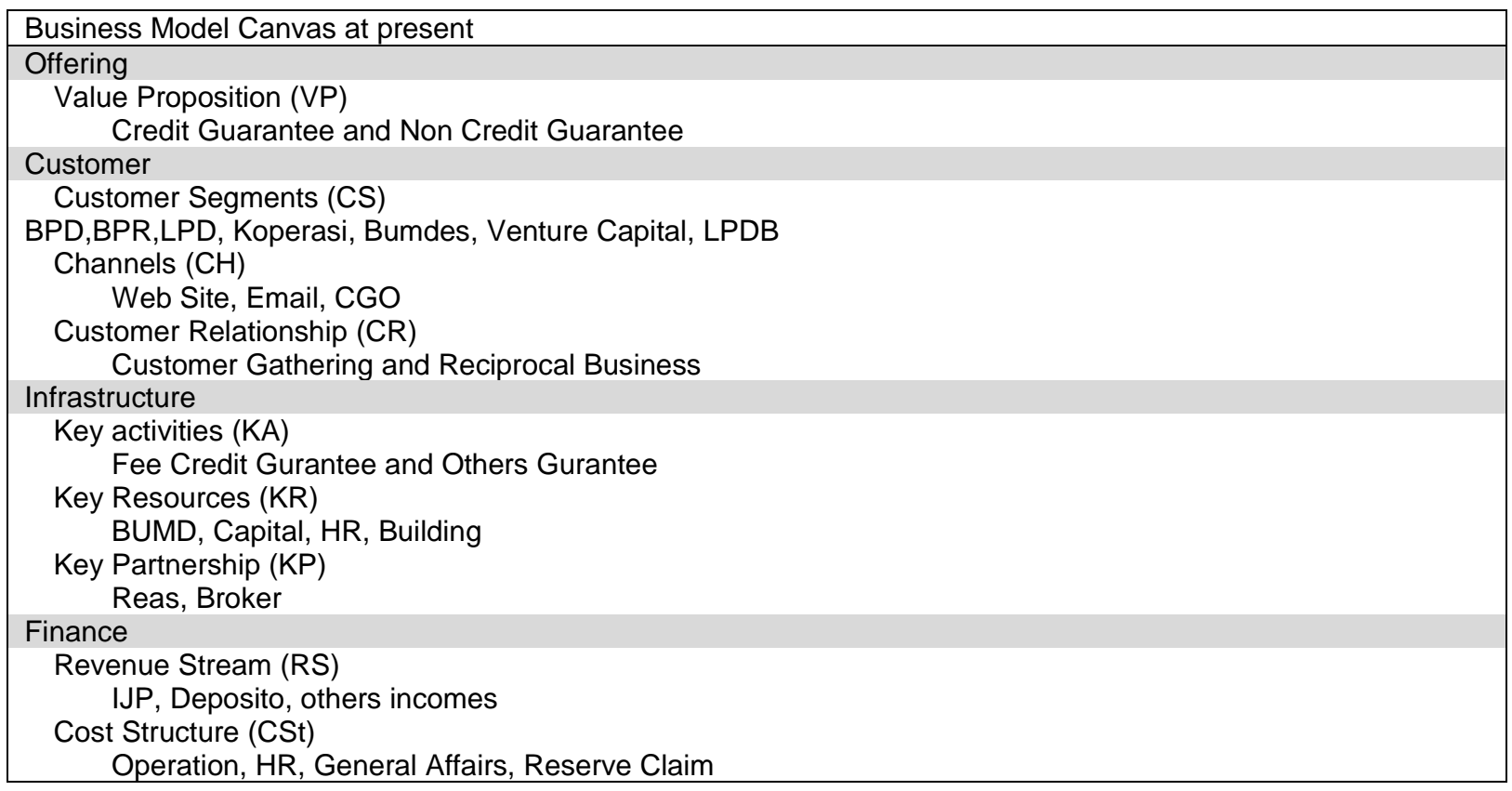

Before using matrix IFAS and EFAS, identify strength, weakness, opputunity and threats from internal and external factors from the business model at the times as show in Table 5.

Based on Table 7, the total score of weighted score is 3.116. From the total weighted score, it can be concluded that the company is in a strong position. This is because the company's internal conditions are above the average value of 2.50. This condition shows that JBM internal factors are relatively strong in utilizing the strengths they have and are able to overcome weaknesses. The main strength possessed by JBM is the speed of payment of claims with a score of 0.271 , and then the second power is occupied by payment of claims to banks and partners with a score of 0.268 . Good relations with partners are in third place with a score of 0.257 . Whereas more trust by banks and as BUMDs in the area of regional credit guarantee occupies the fourth and fifth positions with scores of 0.254 and 0.249 respectively. The main weakness possessed by JBM is the risk of claims that are fully borne by the company with a score of 0.104 . In the second position is relatively limited capital with a score 
of 0.108 . In the third and fourth positions are IT systems that have not been integrated and the limitations of human resources who have knowledge in the field of credit guarantee with a score of 0.111 and 0.120 respectively.

Table 5 - Current Internal Strategy Factors against Business Canvas Models

\begin{tabular}{|c|c|c|c|c|c|c|c|c|c|c|}
\hline \multirow{2}{*}{ No } & \multirow{2}{*}{ Internal Strategy Factor } & \multicolumn{9}{|c|}{ Business Model Canvas Saat Ini } \\
\hline & & VP & CS & $\mathrm{CH}$ & $\mathrm{CR}$ & KA & $\mathrm{KR}$ & KP & RS & CSt \\
\hline \multicolumn{11}{|c|}{ Strenght (S) } \\
\hline 1 & Speed of decision approval credit guarantee & VP & & & & & & & & \\
\hline \multirow[t]{2}{*}{2} & Payment of Claim to The Bank & VP & & & & & & & & \\
\hline & And partner & & & & & & & & & \\
\hline 3 & Good Relationship within partner & & & & $\mathrm{CR}$ & & & & & \\
\hline 4 & A state owned company & & & & & & KR & & & \\
\hline 5 & Trusted From Banks and Partners & & CS & & & & & & & \\
\hline 6 & Product of Guarantee to all risk & VP & & & & & & & & \\
\hline 7 & Holding Account IJP each partner & & & & $\mathrm{CR}$ & & & & & \\
\hline 8 & Placement Deposito each partner & & & & $\mathrm{CR}$ & & & & & \\
\hline 9 & Credit Guarantee Officer cover area Bali & & & $\mathrm{CH}$ & & & & & & \\
\hline 10 & Business coverage all area in Bali & & & $\mathrm{CH}$ & & & & & & \\
\hline \multicolumn{11}{|c|}{ Weakness (W) } \\
\hline 11 & Talented Human Resources & & & & & & KR & & & \\
\hline & On Credit Guarantee business & & & & & & & & & \\
\hline 12 & Limited Capital & & & & & & KR & & & \\
\hline 13 & Risk of Claim totally obligated by company & & & & & & & $\overline{\mathrm{KP}}$ & & \\
\hline 14 & Limited personnel to cover area business & & & & & & $\mathrm{KR}$ & & & \\
\hline 15 & Unintegrated IT System within partnerts & & & $\mathrm{CH}$ & & & & & & \\
\hline 16 & $\begin{array}{l}\text { Limited Marketing Communication for product } \\
\text { and services of company }\end{array}$ & & CS & & & & & & & \\
\hline
\end{tabular}

Table 6 - External Strategy Factor To Business Model Canvas at present times

\begin{tabular}{|c|c|c|c|c|c|c|c|c|c|c|}
\hline \multirow{2}{*}{ No } & \multirow{2}{*}{ External Strategy Factor } & \multicolumn{9}{|c|}{ Business Model Canvas at present times } \\
\hline & & VP & CS & $\mathrm{CH}$ & CR & $\mathrm{KA}$ & $\mathrm{KR}$ & $\mathrm{KP}$ & $\mathrm{RS}$ & CSt \\
\hline & Opportunity (O) & & & & & & & & & \\
\hline 1 & Increasing Finance Business of LKB and LKBB & VP & & & & & & & & \\
\hline 2 & Government Policy To SMEs & VP & & & & & & & & \\
\hline 3 & Total SMEs which is not using the JBM services & & CS & & & & & & & \\
\hline 4 & Condition of Banking Business & & CS & & & & & & & \\
\hline 5 & Segment market still open widely & & CS & & & & & & & \\
\hline 6 & Application of Credit Guarantee & & & & & & KR & & & \\
\hline & Regulations & & & & & & & & & \\
\hline 7 & Opportunity to collaborate with Fintech business based on P2P & & CS & & & & & & & \\
\hline 8 & Opportunity to Publish a Surety Bond & & & & & KA & & & & \\
\hline 9 & Limited Number of Guarantee Credit Company in Bali & & & & & $\mathrm{KA}$ & & & & \\
\hline & Treath $(\mathrm{T})$ & & & & & & & & & \\
\hline 10 & Competition with others company who running same business & & & & & KA & & & & \\
\hline 11 & Highest Tariff of Reward Guarantee & & & & & & & & RS & \\
\hline 12 & Ability to pay risk of Credit/ Claim & & & & & & & & & CSt \\
\hline 13 & Moral Hazard Risks & & & & & & & KP & & \\
\hline 14 & Missunderstanding about fuction of Insurance and Credit Guarantee & & & & & KA & & & & \\
\hline 15 & Some Government regulation still not support this business & & & & & & KR & & & \\
\hline
\end{tabular}

Based on the data, the total weighted score is 3.160. This shows that JBM is able to respond to external factors by utilizing existing opportunities to overcome threats. From the total value it can be concluded that the company is in a strong position in facing opportunities and overcoming threats with a weighted total score higher than the average value of 2.50 . The main opportunity faced by JBM is the plan to increase the financing of Bank Financial Institutions and Non-Bank Financial Institutions with a score of 0.305 . In the second position is the development of banking conditions with a score of 0.301 . The large number of UKMK while there are still many who have not been guaranteed to occupy the third position with a score of 0.297 , while in the fourth position was occupied by government policy support for UKMK with a score of 0.293 . 
Table 7 - Internal Factor with Matrik IFAS

\begin{tabular}{|c|c|c|c|c|c|}
\hline \multirow{2}{*}{ No } & \multirow{2}{*}{ Internal Strategy Factor } & Quality & Rating & Amount & \multirow{2}{*}{ Comment } \\
\hline & & $\mathrm{a}$ & $\mathrm{b}$ & $a \times b$ & \\
\hline \multicolumn{6}{|c|}{ Strenght (S) } \\
\hline 1 & Speed of approval decision credit guarantee & 0.070 & 4 & 0.271 & Improve \\
\hline 2 & Payment claim to banking and Partners & 0.071 & 4 & 0.268 & Improve \\
\hline 3 & Relationship to partners & 0.069 & 4 & 0.257 & Improve \\
\hline 4 & A states owned company & 0.072 & 3 & 0.249 & Keep up \\
\hline 5 & Trusted from partners and public & 0.070 & 4 & 0.254 & Improve \\
\hline 6 & Product Guarantee for All Risk & 0.066 & 3 & 0.198 & Developed \\
\hline 7 & Holding Account IJP at partners & 0.057 & 3 & 0.145 & Keep up \\
\hline 8 & Placement Deposito at Partners & 0.072 & 3 & 0.235 & Keep up \\
\hline 9 & Credit Guarantee Officer cover all area & 0.063 & 3 & 0.199 & Adding Personel \\
\hline 10 & Business area coveraged Bali & 0.070 & 3 & 0.229 & Developed \\
\hline \multicolumn{6}{|c|}{ Weakness (W) } \\
\hline 11 & Talented Human Resources & 0.053 & 2 & 0.120 & Improve the ability \\
\hline 12 & Limited Capital & 0.051 & 2 & 0.108 & Adding \\
\hline 13 & Claim risk obligated of company & 0.043 & 2 & 0.104 & Risk Mitigation \\
\hline 14 & Limited personnel to cover Bali area & 0.058 & 3 & 0.159 & Add Personnel \\
\hline 15 & Unintegrated IT System within partnerts & 0.051 & 2 & 0.111 & Developt the System \\
\hline 16 & Limited Marketing Communication for product and services of company & 0.062 & 3 & 0.209 & Social media champaign \\
\hline
\end{tabular}

Table 8 - External Factor with Matrik IFAS

\begin{tabular}{|c|c|c|c|c|c|}
\hline \multirow{2}{*}{ No } & \multirow{2}{*}{ External Strategy Factors } & Quality & Rating & Amount & Comment \\
\hline & & $\mathrm{a}$ & $\mathrm{b}$ & $a \times b$ & \\
\hline \multicolumn{6}{|c|}{ Opportunity $(\mathrm{O})$} \\
\hline 1 & Increasing Finance business to LKB and LKBB & 0.0791 & 4 & 0.305 & Product Development \\
\hline 2 & Government policy to SMEs & 0.0791 & 4 & 0.293 & Markom to SMEs \\
\hline 3 & Total SMEs which is not using JBM services. & 0.0791 & 4 & 0.297 & Markom to SMEs \\
\hline 4 & The condition of Banking business & 0.0791 & 4 & 0.301 & Product Development \\
\hline 5 & Market still open widely & 0.0791 & 3 & 0.206 & Market Penetration \\
\hline 6 & Aplication of Regulation for Credit Guarantee company & 0.0732 & 3 & 0.245 & Government regulation \\
\hline 7 & Opportunity to collaborated with Fintech based on P2P & 0.0663 & 3 & 0.169 & Sytem Online \\
\hline 8 & Opportunity to publish a Surety Bond & 0.0732 & 3 & 0.194 & Markom of product \\
\hline 9 & Limited number of company credit guarantee & 0.0732 & 2 & 0.165 & Market Penetration \\
\hline \multicolumn{6}{|c|}{ Treath $(\mathrm{T})$} \\
\hline 10 & Competition with other company who run same business & 0.0514 & 3 & 0.136 & Internal Consolidation \\
\hline 11 & Highest Tariff of Reward Guarantee & 0.0564 & 3 & 0.149 & Evaluation \\
\hline 12 & Ability to pay risk of claim/credit & 0.0544 & 3 & 0.152 & Risk Mitigation \\
\hline 13 & Risk of moral hazard & 0.0366 & 2 & 0.070 & Risk Mitigation \\
\hline 14 & Missunderstanding of fuction Insurance and Credit Guarantee & 0.0584 & 4 & 0.233 & Markom Product and Services \\
\hline 15 & Some Government regulation not support this business & 0.0613 & 4 & 0.245 & Government Regulation \\
\hline
\end{tabular}

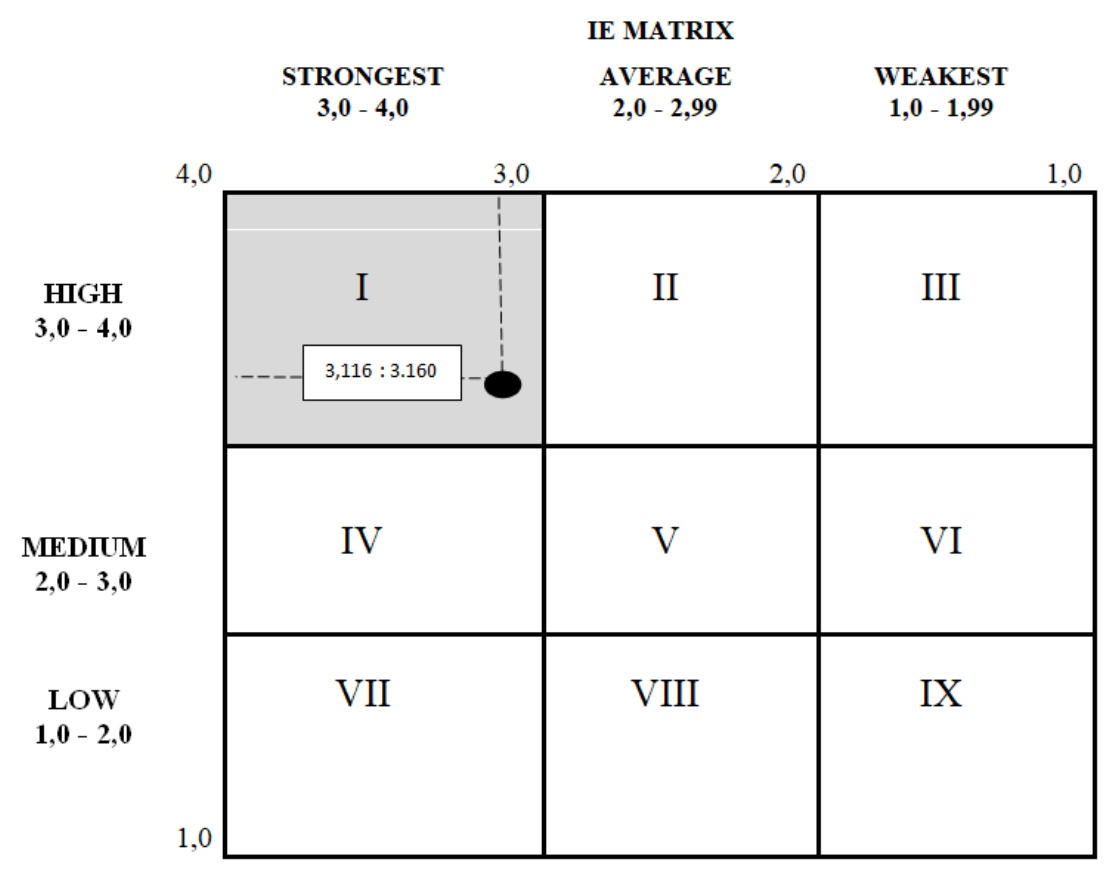

Figure 2 - Matrix IE (Source: Rangkuti, 2001) 
The main threat faced by JBM is the risk of the emergence of moral hazard with a score of 0.070 . Competition arising from similar companies is in second place with a score of 0.136. Whereas for the third and fourth position, the Guaranteed Service Fee rate is relatively high and the ability to pay credit risk / claims with a score of 0.149 and 0.152 respectively.

From the calculation of EFAS and IFAS Matrix the position of JBM is in cell I, including grow and build. The strategy that fits this area is an intensive strategy, such as market penetration, market development or product development to achieve growth, whether in sales, assets or profits, or a combination of the three. This can be achieved by reducing prices, developing new products, increasing the quality of products or services, or increasing access to a wider market. The business that can be done is by minimizing costs (minimizing costs) so that it can increase profits. This method is the most important strategy if the condition of the company is in rapid growth and there is a tendency of competitors to carry out price wars in an effort to increase market share. Thus, companies that have not reached critical mass (profit from large-scale production) will experience defeat, unless the company can focus on certain profitable markets.

Table 9 - Matrix Internal and External

\begin{tabular}{|c|c|c|}
\hline $\mathrm{n} / \mathrm{n}$ & Strenght $(\mathrm{S})$ & Weakness (W) \\
\hline IFAS & $\begin{array}{l}\text { Speed of approval decision } \\
\text { Payment claim to Banking and Partner } \\
\text { Relationship to Partner } \\
\text { A state owned company }\end{array}$ & $\begin{array}{l}\text { Talented Human Resources on } \\
\text { Guarantee business } \\
\text { Limited Capital } \\
\text { Risk of Claim } \\
\text { Amount of Personnel to cover area }\end{array}$ \\
\hline EFAS & $\begin{array}{l}\text { Trusted from Partner and Public } \\
\text { Product Guarantee for All Risk } \\
\text { Placement Deposito on all partner } \\
\text { Holding Account for IJP on all partner } \\
\text { Credit Guarantee Officer covering area } \\
\text { Bali } \\
\text { Business coverage Bali area }\end{array}$ & $\begin{array}{l}\text { Unitegrated IT System within } \\
\text { partner } \\
\text { Markom for product and services }\end{array}$ \\
\hline Opportunity $(\mathrm{O})$ & Strategy SO & Strategy WO \\
\hline $\begin{array}{l}\text { Financing Bank and Non Bank increase } \\
\text { Support Regulation from Government } \\
\text { Big Size Market SMEs still not grab } \\
\text { Condition of banking Business } \\
\text { Market segment of BPR, LPD, Koperasi still } \\
\text { widely open } \\
\text { Opportunity collaborated with Fintech } \\
\text { Opportunity to publish Surety Bond } \\
\text { Limited company of guarantee credit in Bali }\end{array}$ & $\begin{array}{l}\text { a. Market Penetration Strategy (S1, S2, } \\
\text { S3, S5, S6, O1, O2, O3, O5, O9) } \\
\text { b. Market Development (S1, S2, S3, S4, } \\
\text { S5, S6, S9, S10, O1, O2, O3, O5, O6, } \\
\text { O7) } \\
\text { c. Product Development (S1, S2, S3, S4, } \\
\text { S5, S6, S7, S8, O1, O3, O5, O7, O8) }\end{array}$ & $\begin{array}{l}\text { a. Improving ability and add } \\
\text { personnel CGO (W1,W2,O1,O3,O5) } \\
\text { b. Incresing Capital (W2, W3, W4, } \\
\text { W5, O1, O3, O5, O7, O8) } \\
\text { c. Integrated IT System, launch } \\
\text { Mobile Application (W4, W5, O1, } \\
\text { O5, O7, O8, O9) }\end{array}$ \\
\hline Threat (T) & Strategy ST & Strategy WT \\
\hline $\begin{array}{l}\text { Competition within other company with } \\
\text { similar business } \\
\text { The relatively high rate of guarantee service } \\
\text { returns } \\
\text { Ability to pay risk/credit } \\
\text { Moral hazard risks } \\
\text { Missunderstanding Fuction of Insurance and } \\
\text { Credit Guarantee } \\
\text { Unintegrated regulation from government }\end{array}$ & $\begin{array}{l}\text { a. Internal consolidation and } \\
\text { Improvement } \\
\text { b. Risk-based for Tariff Evaluation (S1, } \\
\text { S3, S5, S6, T1, T2) } \\
\text { c. Risk Mitigation (S1, S2, S3, S6, T1, } \\
\text { T3, T4, T6) } \\
\text { d. Differencial (S4, S5, S10, T2, T3, T4) }\end{array}$ & $\begin{array}{l}\text { a. Product Inovation (W6, T1, T4, } \\
\text { T6) } \\
\text { b. Social Media champaign } \\
(\mathrm{W} 1, \mathrm{~W} 3, \mathrm{~W} 4, \mathrm{~T} 1, \mathrm{~T} 3, \mathrm{~T} 4, \mathrm{~T} 5)\end{array}$ \\
\hline
\end{tabular}

JBM has to focus on products of Credit Guarantee. This strategy shown on Speed of approval decision (S1), Payment Claim (S2), Relationship with Partner (S3), Trusted (S5), Product of Guarantee (S6) related to Increasing Condition Financing (O1), Government Regulation (O2), Total amount of SMEs (O3), Widely Market (O5), Limited Competitor (O9). The Goal of Market Penetration: 1) Maintaining and increasing market share through Product Combination with competitive IJP, 2) Structuring market with right calculation to avoid competitor influences, 3) Increasing benefit Guarantee Credit to partner and customer.

JBM strategy to developing the potential through team unit to increasing benefit for customer and partner and prospectus customer and partner. Using Strengh point $(\mathrm{S} 1, \mathrm{~S} 2, \mathrm{~S} 3, \mathrm{~S} 4, \mathrm{~S} 5, \mathrm{~S} 6, \mathrm{S9}, \mathrm{S} 10)$, JBM has to get potential market according to biggest amount of SMEs which is not using credit guarantee, with support by $(01,02,03,05,06,07)$. Key of 
Succes by adding personnel of Credit Guarantee Officer (S9) in every market segment such as BPR, LPD, Koperasi Simpan Pinjam, Bumdes and Fintech.

Product Development; JBM has to create varioust product but related to Government regulation (Financial Services Authority Regulation: POJK No 6/POJK.05/2014 about operating business credit guarantee).

Strategy $S-T$, the result is internal consolidation to all resources of company through: a) automazie procedure and activity with IT development, b) Improving skill and ability personnel through couching and training, c) Increasing relationship and appreciation to partner through visiting, gathering, discussing, seminar, etc

Evaluation Tariff IJP based on Risk; The goals are increasing quality of services to SMEs to easy acces get the credit guarantee services of JBM (S1, S3, S5, S6). With do this evaluation, in order to increasing volume of credit guarantee from SMEs UMKM (T1, T2). This way has to do soon regarding the competitor act the same strategy.

Continuing Action Plan from JBM to reduce impact of potential loses the business (S1, S2, S3, S6, S7). Such as: 1) Avoid; Terminated Program or Activity, 2) Reduce; Anticipating action, example likes create new SOP (Standart Operation Procedure) on Analize Credit Guarantee, Claim , Risk Management, 3) Share; A solution with move the risk to other party, example likes collabotared with Broker Agent, Re Insurance/ Co Guarantee, 4) Accept; A solution with make a Reserve Loses or Claim $(\mathrm{T} 3, \mathrm{~T} 4, \mathrm{~T} 6)$ and make a Disaster Recovery Plan, because sometimes the risk could not avoid but could anticipatated

JBM do differentiation to achieve a unique product that can not copy by competitor and give a add value to customer, parnert and public (S4, S5, S10). The product has to competitive rather than others (T2, T3, T4).

Clear job description will make employee focus on their job and responsibility (W1, W2,). In the future need to development the organization structure through make a working section likes: 1) Credit Guarantee Department, 2) Non Credit Guarantee Department, 3) Claim and Subrogasi Deparment, 4) Risk Management Department and 5) Investment Deparment. Increasing number of CGO in every segment will make a impact to quality of services and grab the bigger market $(\mathrm{O} 1, \mathrm{O}, \mathrm{O})$.

Gearing Ratio depend on capital of JBM (W2, W3, W4, W5), the bigger capital, the bigger ability to guarantee. (O1, O3, O5, O7, O8). From total capital IDR 130 Millions, JBM has capacity to guaranteed IDR 5,2 Triliuns. Hence, until 2017, Total Credit that JBM did the guarateed: IDR 5,7 Triliun.

Integrated System and Mobile Application; Integrated system will make work easier and reduce the times, easy to reporting, monitoring and evaluation because can provide proper data (W4, W5). The goal also to give fast and proper information to reduce the times of operation, procedure and services to customer and partner $(01,05,07,08,09)$.

Activity to makes a product one step a head from competitor and customer needs.(W6). JBM has a Guarantee of Custom Bond for SMEs expecially on export import Furthermore; JBM could make a Guarantee for Letter of Credit. This product has to approve by goverment. By developing the product, JBM could anticipating the competition with others company in the future times (T1, T4, T6). Inovation is very important to do by JBM in order to: 1) Inovation as a improvement of product, 2) Inovation for increasing total omzet, 3) Inovation as a quality of company performances, 4) Inovation for compete with competitor.

Create new inovation to accommodate the need of SMEs and deliver the benefit and advantes of the product by using social media such as Facebook, Instagram, Youtube, also give a training to personnel about IT and Social media to make their updating with IT and aware with change of business condition, market conditions(W1, W3, W4, W5). Human resources development also has to improve by recruit potential personnel and upgrade ability the staff and leader to anticipating the fast of changing in tis business (T1, T3, T4, T5).

Based on the corporate strategy and alternative strategy mapping above, then the description of the elements that make up each element in the 9 (nine) elements of the Canvas Business Model at PT. Jamkrida Bali Mandara for the long term in the future is described as follows: 
Customer Segments, customer segmentation is designed to increase customer value or profitability through careful customer targeting. (Chan, 2005; Chung et al., 2004; Hwang et al., 2004; Jones et al., 2006; Kim and Street, 2004; Kim et al., 2005; Kuo et al., 2006; Shin and Sohn, 2004; Woo et al., 2005). Based on the results of the SWOT analysis, elements in the segment of JBM customer segments undergo segment changes such as a). Financing Agency, b) Mortgage, c) Fintech Company, d) Company or Institution channeling Partnership and Community Development Program (PKBL). Besides the development of a new segment, JBM will also increase the number of partners.

The process of creating value involves suppliers to create superior value propositions, customers determine the goods or services needed. A superior value proposition must produce greater opportunities to create results for benefits or values received by suppliers by means of income, profits and references. Because of successfully managing the creation and exchange of values, companies can try to maximize the value given continuously to the desired customer segment (Payne and Frow, 2005). JBM Core Business in the field of credit guarantee will still maintain the guarantee products that have been running so far. Value Proposition elements will add several products and services to partners and service users, including the following: a) Conduct credit guarantees and / or partnership program loans channeled by state-owned enterprises in the framework of the Partnership and Community Development Program (PKBL); b) Guarantee the distribution of loan money guaranteed by pawn and fiduciary; c) Guarantee on debt securities; d) Guarantee on commercial transactions; e) Guarantee the letter of credit (L / C); f) Providing management consulting services related to guarantee business activities; g) Providing information / databases Guaranteed related to guarantee business activities; and / or h) Conduct other guarantees after obtaining approval from the Minister.

Customer Relationship (how to maintain good relationships with consumers), Rönroos (1994) defines customer relationships as an organizational effort directed at building, maintaining and developing relationships with customers and other partners, relationships that can be divided into two parts: to attract customers and build relationship with customers, so that business goals are achieved. Based on the results of the SWOT analysis, customer relationships elements have added elements of the "Customer Forum and Marketing Summit". This element is a tool that will be used to build communication and relationships with customers. Institutional customer forums are institutions or forums formed by customers facilitated by PT. Jamkrida Bali Mandara. While the Marketing Summit will be routinely held to be able to provide information about market share from partners while providing rewards or awards for partners who contribute the most performance to JBM. This activity can be integrated with the Economic Outlook for partners to be able to know the economic situation in a macro and micro way. The Customer Relationship element will change to: a) Customer Gathering; b) Reciprocal Business; c) Customer Forum; d) Marketing Summit.

Channels (media used to reach customers), From a marketing perspective, using different channels will provide different types of services and the output will vary. Internet channels are very strong in providing information to customers, thereby reducing costs incurred. Offering multiple complementary channels provides a greater and deeper combination of services to customers, thereby increasing the overall value proposition from the seller (Wallace et al., 2004). Channel preferences vary among customers. But even individual customers are increasingly becoming multi-channel buyers, preferring different channels at different times and at different stages of the shopping process (Nunes and Cespedes, 2003). From the perspective of operations management, multi-distribution can produce synergies that help reduce costs for meeting needs (de Koster, 2002, Lummus and Vokurka, 2002). Thus, companies need to make trade-offs when deciding which processes are integrated across all channels and which processes should be separated (Gulati and Garino, 2000). Based on the results of the SWOT analysis, elements of the channels did not change from the previous one. These elements include: website, e-mail, and Credit Guarantee Officer (CGO). But what has increased is that the amount of CGO will be added according to the increasing number of partners. To support the plan to increase the number 
of CGOs, JBM will develop an integrated system between JBM-Broad-Partner Partners as potential customers of Bank and Non-Bank Financial Institutions.

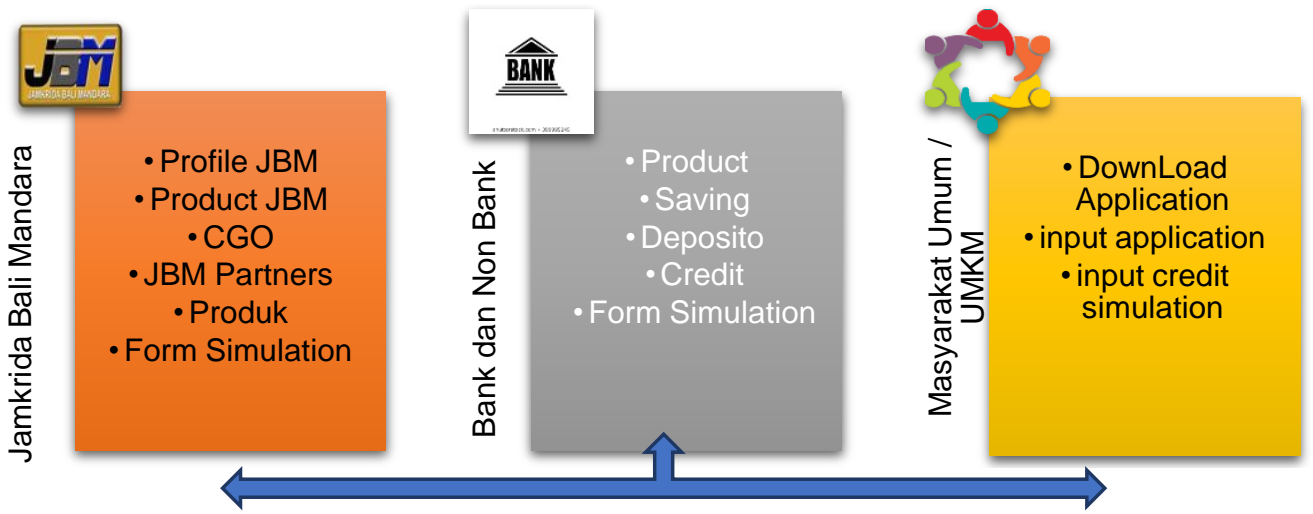

Figure 3 - Integrated system between JBM-Broad-Partner Partners

Table 10 - Business Models

\begin{tabular}{|c|c|}
\hline Business Model Canvas 2018 & Business Model Canvas $\mathrm{n}$ the Future \\
\hline \multirow{2}{*}{\multicolumn{2}{|c|}{$\begin{array}{l}\text { OFFERING } \\
\text { Value Proposition (VP) }\end{array}$}} \\
\hline & \\
\hline Credit Guaraantee: Micro, Multiuse & $\begin{array}{l}\text { Credit Guarantee: } \\
\text { PKBL, Pawn/ Fiducia, Letter of Debt, }\end{array}$ \\
\hline Construction and procurement, Linkage, & $\begin{array}{l}\text { Letter of Credit, Consultant, Database and } \\
\text { Information }\end{array}$ \\
\hline Non credit: Surety Bond, Counter & Guarantee Non Credit: warehousing \\
\hline \multicolumn{2}{|l|}{ Bank Guarantee (KBG), Custom Bond } \\
\hline \multicolumn{2}{|l|}{ CUSTOMER } \\
\hline \multicolumn{2}{|l|}{ Customer Segments (CS) } \\
\hline $\begin{array}{l}\text { BPD ( } 51 \text { Kantor Cabang),BPR (90 BPR), } 177 \text { LPD, } 65 \mathrm{KSP} \text {, } \\
16 \text { BUMDES, } 1 \text { Bank Umum, } 1 \text { Modal Ventura and Gapensi }\end{array}$ & $\begin{array}{l}\text { BPD Bali, } 47 \text { BPR, } 1256 \text { LPD, } 1179 \text { KSP, } 318 \\
\text { Bumdes, Financial Institution, Fintech, Pawn and } \\
\text { PKBL }\end{array}$ \\
\hline \multicolumn{2}{|l|}{ Channels $(\mathrm{CH})$} \\
\hline Web Site, Email, CGO & $\begin{array}{l}\text { website, e-mail, Credit Guarantee Officer (CGO) } \\
\text { and Integrated System }\end{array}$ \\
\hline \multicolumn{2}{|l|}{ Customer Relationship (CR) } \\
\hline \multirow{2}{*}{ CuCustomer Gathering Reciprocal Business } & $\begin{array}{l}\text { Customer Gathering, Reciprocal Business, } \\
\text { Customer Forum. Marketing }\end{array}$ \\
\hline & Summit \\
\hline \multicolumn{2}{|l|}{ INFRASTRUCTURE } \\
\hline \\
\hline & Credit Guarantee and other Guarantee \\
\hline \multicolumn{2}{|l|}{ Key Resources (KR) } \\
\hline BUMD, Capital, HR, Building & Capital Additions, HR Development \\
\hline \multicolumn{2}{|l|}{ Key Partnership (KP) } \\
\hline Re Insurance, Broker Agent & Co Guarantee and Re Guarantee \\
\hline \multicolumn{2}{|l|}{ FINANCE } \\
\hline \multicolumn{2}{|l|}{ Revenue Stream (RS) } \\
\hline IJP sources from Product Credit Guarantedari Product & IJP sources from Credit Guarantee and Non \\
\hline Deposito, Coupon Rate, others income & $\begin{array}{l}\text { Credit, Deposito, Re Insurance Commissions, } \\
\text { other income }\end{array}$ \\
\hline \multicolumn{2}{|l|}{ Cost Structure (CSt) } \\
\hline $\begin{array}{l}\text { Operation ,HR, General, Claim Reserve, } \\
\text { ReAssuransi }\end{array}$ & $\begin{array}{l}\text { Dicrease of Claim Reserve because sharing risk } \\
\text { with other ( Broker Agent) }\end{array}$ \\
\hline
\end{tabular}

Revenue Stream (source of income), Integration of business models involves combining customer models, value models, and revenue models. Because each different type of customer model (segmentation) can support various models of customer income and value, it is possible to develop several streams in each of these models - we call them 
"business model integration" (Novak and Hoffman, 2001). Revenue Stream is cash flow obtained by the company from each customer segment. Revenue Stream describes how companies get money.

SWOT Analysis Key Resources has not changed, but the most important point made by JBM is to approach all Shareholders in order to increase capital participation to JBM which aims to increase capacity to guarantee capacity (Gearing Ratio) so that it is expected to fulfill what will be offered in the Value Proposition. The potential for additional partners is still very possible, but if the guarantee capacity is still limited, it will be very difficult for future development plans to be achieved.

Based on SWOT Analysis, adding activity of company as mention below: 1) Giving Credit Guarantee to cover the risk of payment of guarantee recipients if recipient could not fulfill its obligation. 2) Beside of that activity, JBM could do other activity to create varioust product but related to Government regulation (Financial Services Authority Regulation: POJK No 6/POJK.05/2014 about operating business credit guarantee).

Willis and Huston (1990) emphasize how importance of business relationship is as important as marriage, trusted and openness information between each party are mainly based of good relationship. Landry et al., (1998) seen that succesfull relationship from cost of transactions and relationship is about comtroll cost of transactions. Key Partnership based on SWOT Analysis is Amount of partner need to add in order to increasing services and capacity of JBM. The important things are about how the perfomances of JBM could Share the Risk and increasing services to partner in term of their scheme.

Based on SWOT Analysis, there is no changing on cost structure but it will be useful on the future regarding decrease of claim obligate because JBM do Risk Mitigation through collaborated with Re Insurance / Re Guarantee, Broker Agent based on agreement to share the risk.

\section{RESEARCH IMPLICATIONS}

Based on the results of research on reformulating business strategies to increase credit guarantee at PT. Jamkrida Bali Mandara by using SWOT Analysis and the Business Model Canvas approach can make an alternative in preparing a business strategy for the company, as well as this research as an enrichment theory and can be used as a reference for future researchers.

The contribution of the results of this study can be used as a reference for PT. Jamkrida Bali Mandara to make good improvements internally, so that by implementing a new Business Model, it can improve company performance. There are several future policies that need attention for the management of PT. Jamkrida Bali Mandara as follows: a. Focus on developing market potential, b. Do product development, c. Immediately develop in the field of Information Technology so that the development goals can be achieved, among others; Cross Selling Products, Education to End Users, increase Value, create cost efficiency and can improve financial performance, and $d$. Collaborating with the Agency Company to be able to increase the number of Credit Guarantee Officers according to the target partners.

From the results of this study obtained several things that can be used as material for consideration for Provincial and District and City Governments to further increase their participation in the development of PT. Jamkrida Bali Mandara. The things that can make the attention of the Regional Government are as follows: a. MSMEs as a driver of the regional economy, b. Government policy in developing MSMEs through People's Business Credit, c. The Role of Regional Financial Institutions that play a role in developing MSMEs through Micro Credit and Regional KUR, d. There are still many MSMEs that are Feasible but not Bankable which must be more developed in access to finance., e. The role of MSMEs engaged in the creative economy needs to get policy support from the Regional Government, f. Growing Entrepreneurship Start Up, g. Adding Equity Participation to PT. Jamkrida Bali Mandara, so that in the future PT. Jamkrida Bali Mandara can be more important to open access to finance through micro credit guarantee. 


\section{LIMITATIONS OF RESEARCH}

Resercher has realize the limitations of this research such as small population sample, writting technique, analysis, etc; but hoping this research could be useful as a references for people who involved on SMEs, Credit Guarantee, Government Policies, Financial Institutian, $\mathrm{NGO}$ and Academic Institutions. Because the limitations of this research, the next research on the same issue or object suggest to concern on: more sample to get objective result, similar object research, and other methods of research.

\section{CONCLUSION AND SUGGESTIONS}

Strenght: approval speed on Credit Guarantee, Payment for Claim to Banking, Good business relationship to partner, Trusted from partner. Weakness: Claim Risk lay on their own obligations, Limited Capital to guarantee potential size market of credit in Bali, Unintegrated system in running the business, Ability of personnel to running operation related to skills on credit guarantee. Opportunity: Growth of Credit in Bali, Banking Business Condition, Big Number of polupation SMEs not reach to accces Credit Guarantee, Government policies to encourage SMEs. Threats: Moral Hazard Risk, Competition with other Guarante Credit Company, Highest Tariff Fee Gurantee.

Strategy and Model Business for future plan for JBM:

- Customer Segment; Collaboration with new partners;

- Value Proposition; Offering new product to anticipating the competation and and fulfill the demands such as: Guarantee for LC, Pawn, Letter of Trade, Consultant Management, IT and database, etc;

- Customer Relationship; to reach, maintains and increasing relationship to customer, JBM do some activity such as: Customer Forum, Marketing Summit, Customer Gathering and Reciprocal Business;

- Channels; JBM using establish channel and develop the integrated system among the each channel ( JBM, - Partner - Public as prospectus customer);

- Revenue Streams; JBM developing other incomes sources as impact of adding value proportion, such as: Incomes from Credit Guarantee government, LC., LD, Pawn, Consultant, Database and IT;

- Key Resources; JBM has to approach share holders to adding capital for increasing ability to guarantee, because of big potential market size and volume of credit guarantee in Bali;

- Key Activities; JBM could develop and expand the business as long follow government regulation Undang Undang No 1 Tahun 2016 about Credit Guarantee Company;

- Key Partnership; JBM partners and collaborated with Broker Agent and Re Insurance to sharing risk;

- Cost Structure; JBM did mitigation risk through collaborate with Broker Agent and Re Insurance to sharing risk based on mutual agreement.

Suggestions:

- Based on core company business to cover the risk, JBM has to do Risk Mitigation to reduce the risk so JBM could growth continously and maintain performances ablity and capacity to guarantee;

- It is important to focus on core business on Credit Guarantee, maintain the achievement and maintain the trusted from partner, customer and public. Some issues has to concern: a) Trusted on payment claim, b) Speed of services bring the good images of company, c) Capital Power Reputation;

- Using and developing integrated IT system to reduce cost and times to achieve best services; 
- Struggle with former VISION and MISION to accommodate goals of JBM and shareholder to encourage SMEs in Bali in order to growth economy in Bali and Indonesia.

\section{REFERENCES}

1. Angipora, M. P. 2002. Dasar-dasar Pemasaran. PT. Raja Grafindo Persada, Jakarta.

2. Afuah - Tucci, 2003. Internet Business Models and Strategic Text and Cases. The McGraw-Hill Companies.

3. Afuah A. 2004. Business Models, A Strategic Management Approach. New York: McGrawHill

4. Christensen CM. 2001. The past and future of competitive advantage. MIT Sloan Management Review 42:105-109.

5. Christoph Zott and Raphael Amit. 2009. Business Model Design: An Activity System Perspective. Long Run Planning (LRP), http://www.elsevier.com/locate/lrp.

6. Christoph Zott, Raphael Amit, Lorenzo Massa, 2010 IESE Business School, the Business Model: Theoretical Roots, Recent Development, and Future Research.

7. Cavalcante Se'rgio, Peter Kesting and John Ulhoi, 2011, Business Model Dynamic and Innovation: (re) establishing the Missing Linkages, Emerald insight journal.

8. Chesbrough H. 2007. Why companies should have open business models. MIT Sloan Management Review 48(2):8-22.

9. Chesbrough Henry, 2009. Business Model Innovation: Opportunities and Barriers, Long Range Planning, Elsevier.

10. Chan, Chu-Chai Henry (2005). Online auction customer segmentation using a neural network model. International Journal of Applied Science and Engineering, 3(2), 101-109.

11. Chung, Kyoo Yup, Oh, Seok Youn, Kim, Seong Seop, and Han, Seung Youb (2004). Three representative market segmentation methodologies for hotel guest room customers. Tourism Management, 25, 429-441

12. Duncan, R.B. (1972). Characteristics of Organizational Environments and Precieved Environmental Uncertainty. Administrative Science Quaterly, Vol.17.

13. David, Fred R. 2006. Strategic Management: Concepts and Cases.10 th Edition. (Manajemen Strategis: Konsep-Konsep and Kasus). Edisi Bahasa Indonesia. Jakarta: Salemba Empat.

14. Davenport Thomas H, 2006. Competing on Analytics, Harvard Business Review.

15. Danica D. 2012. Business Model Innovation at PT. Bahma Rotan to Improve its Competitiveness in Europe Final Project [undergraduate thesis]. Bandung: Sekolah Bisnis Manajemen, Institut Teknologi Bandung.

16. de Koster MBM. 2002a. The logistics behind the enter click. In: A Klose, LN Van Wassenhove (Eds), Quantitative Approaches to Distribution Logistics and Supply Chain Management. Springer: Berlin; 2002. p. 131-148.

17. de Koster MBM. 2002b. Distribution structures for food home shopping. International Journal of Physical Distribution and Logistics Management 32(5): 362-380.

18. Fasha CI, Larso D. 2012. Business model design for new business development at PTB Dialysis Clinic Chain. The Indonesian Journal of Business Administration 1(7):492-499.

19. Fitzroy, P., and Hulbert, J. (2005). Strategiy Management: Creating Value in Turbulent Times. Jhon Wiley.

20. Heidi M. Bertels, Peter A. Koen, and Ian Elsum. 2015. Business Models outside the Core Research-Technology Management.

21. Handoko, Hani. 2003. Manajemen Edisi 2. Yogyakarta: anggota IKAPI.

22. Hwang, Hyunseok, Jung, Taesoo, and Suh, Euiho (2004). An LTV model and customer segmentation based on customer value: A case study on the wireless telecommunication industry. Expert Systems with Applications, 26, 181-188. 
23. Gambardella A., McGahan A.M. 2010. Business-model innovation: General purpose technologies and their implications for industry structure. Long Range Planning Journal 43(2/3):262-271.

24. Giesen E, Riddleberger E, Christner R, Bell R. 2010. When and how to innovate your business model. Strategy and Leadership 38(4):17-26.

25. Grönroos, Christian. (1994). From Marketing Mix to Relationship Marketing: Towards a Paradigm Shift in Marketing. Management Decision,Vol. 32, No. 2, pp. 4-20

26. Gulati R, Garino J. 2000. Get the right mix of bricks and clicks. Harvard Business Review 78(3): 107-114

27. Jaka Lindic and Carlos Marques da Silva. 2011. Value proposition as a catalyst for a customer focused innovation. Emerald Journal, Faculty of Economics, University of Ljubljana, Slovenia.

28. Jones, Joni L., Easley, Robert F., and Koehler, Gary J. (2006). Market segmentation within consolidated E-markets: A generalized combinatorial auction approach. Journal of Management Information Systems, 23(1), 161-182.

29. Kenneth L. Kraemer et al. (2000). Refining and Extending the Business Model with Information Technology: Dell Computer Corporation

30. Kotler and Keller. 2009. Manajemen Pemasaran, Edisi Ketiga Belas Jilid I. Jakarta: Erlangga.

31. Kotler and Armstrong. 2006. Prinsip-prinsip Pemasaran jilid 1 edisi 12. Jakarta Erlangga

32. Kotler, P. 1997. Manajemen Pemasaran (Terjemahan). PT. Gramedia, Jakarta.

33. Kotler, P 2000. Manajemen Pemasaran (Terjemahan Jilid 2). PT. Prenhallindo, Jakarta.

34. Kotler, P 2002. Manajemen Pemasaran (Terjemahan). PT. Prenhallindo, Jakarta.

35. Kartajaya, Hermawan 1999, Siasat Bisnis: Menang and Bertahan pada Abad Asia Pasifik (Business Strategy: Winning and Sustaining in Asia Pacific), diterbitkan oleh PT Gramedia Pustaka Utama in cooperation with Majalah Berita Mingguan Gatra, Jakarta,

36. Kamuriwo DS. 2009. Timing in business model and product market strategy tradeoffs: Performance implications. Academy of Management Proceedings:1-6.

37. Kim, Yong Seog, Street, W. Nick, Russell, Gary J., and Menczer, Filippo (2005). Customer Targeting: A Neural Network Approach Guided by Genetic Algorithms. Management Science, 51(2), 264-276.

38. Kuo, R. J., An, Y. L., Wang, H. S., and Chung, W. J. (2006). Integration of self-organizing feature maps neural network and genetic K-means algorithm for market segmentation. Expert Systems with Applications, 30, 313-324.

39. Lummus RR, Vokurka RJ. 2002. Making the right e-fulfillment decision. Production and Inventory Management Journal 43(1/2): 50-55

40. Landry, Sylvain, Trudel, Yves, and O'Diorio, Mattio: Just-in-Time Supply: Cooperation, Competition, and Abuse. Competitiveness Review 8(1), 37-45 (1998).

41. Lovelock, C. 1999. Manajemen Pemasaran Jasa (Edisi Bahasa Indonesia). PT. INDEKS Kelompok Gramedia, Jakarta.

42. Lestari, Endah Prapti. 2011. Pemasaran Strategik: Bagaimana Meraih Keunggulan Kompetitif Edisi Pertama. Yogyakarta: Graha IImu

43. Mikhail Nikolaevich Dudin, Georgiy Nikolaevich Kutsuri, Irina Jur'evna Fedorova, Svetlana Sozrykoevna Dzusova and Anzhela Zafitovna Namitulina. 2015, the Innovative Business Model Canvas in the System of Effective Budgeting. Asian Social Science; Vol. 11, No. 7; 2015 ISSN 1911-2017 E-ISSN 1911-2025 Published by Canadian Center of Science and Education

44. Makinen Saku and Seppanen Marko, 2007. Assessing Business Model Concepts with Taxonomical Research Criteria, Emerald Insight Journal

45. Margaretta, J. 2002. Why Business Models Matter. Harvard Business Review, 80, 5, 6592.

46. Maghfirah, Alamanda DT, Prasetio A, Prabowo F, Ramdhani A. 2012. E-Business analysis of Garut University (UNIGA) using the business model canvas. International Journal of Science and Research 3(6):529-534.

47. Teguh, 2014, Metode Kuantitatif untuk Analisa Ekonomi and Bisnis, Rajawali Pers. 
48. Nunes PF, Cespedes FV. 2003. The customer has escaped. Harvard Business Review 81(11): 96-105

49. Novak Thomas P and Donna L. Hoffman 2001, Profitability on the Web: Business Models and Revenue Streams Article · January 2001

50. Osterwalder Alexander and Yves Pigneur. 2003. An Ontology for E-Business Models, University of Lausanne.

51. Porter, M. 1993. Strategi Bersaing: Teknik Menganalisis industri and Pesaing (Terjemahan). Erlangga, Jakarta.

52. Payne, Andrian F 1993. The Essence of Services Marketing: Pemasaran Jasa (Terjemahan). Penerbit Andi, Yogyakarta.

53. Payne Andrian F and Kaj Storbacka and Pennie Frow Managing the co-creation of value, Article in Journal of the Academy of Marketing Science - March 2007, ResearchGate.

54. Payne, A., and Frow, P. (2005). A strategic framework for customer relationship management. Journal of Marketing, 69, 167-176.

55. Puspayoga Anak Agung Ngurah, 2015. Industri Penjaminan. Menatap Indonesia Gemilang, Diding S Anwar and Toto Pranoto, Lembaga Manajemen FEB UI.

56. Priandita A., 2013. Business strategy formulation using business model case study: PT. Kartina Tri Satria. The Indonesian Journal of Business Administration 2(1):68-75.

57. Pearce II, Jhon A. and Robinson Jr, Richard B. (2013). Manajemen Strategis: Formulasi, Implementasi, and Pengendalian, Buku 1, Edisi 12. Jakarta. Salemba Empat.

58. Saksono GA. 2013. Kanvas Model Bisnis PT. Fuel Technologies Group Indonesia [tesis]. Bogor: Sekolah Pascasarjana, Institut Pertanian Bogor.

59. Shin, H. W., and Sohn, S. Y. (2004). Segmentation of stock trading customers according to potential value. Expert Systems with Applications, 27, 27-33.

60. Rappa Michael. 2006. Business Models on The Web, http//digitalenterprise.org.

61. Rangkuti, Freddy. 1999. Analisis SWOT Teknik Membedah Kasus Bisnis, PT. Gramedia Pustaka Utama, Jakarta.

62. Rangkuti, Freddy. 2006. Analisis SWOT Teknik Membedah Kasus Bisnis, PT. Gramedia Pustaka Utama, Jakarta.

63. Seddon, P.B., Lewis, G.P., 2003. Strategy and Business Models: What's the Difference. In 7th Pacific Asia Conference on Information Systems, 10-13 July 2003, Adelaide, South Australia.

64. Sukmadinata, N.S. 2011. Metode Penelitian Pendidikan, Cetakan ke Tujuh, Remaja Posdakarya. Bandung.

65. Sugiyono, 2000. Statistik untuk Penelitian, Alfabeta, Bandung.

66. Sugiyono, (2008). Metode Penelitian Kuantitatif Kualitatif and RandD. Bandung: Alfabeta.

67. Sugiyono, 2011. Metode Penelitian Kuantitatif Kualitatif and RND. Bandung: Alfabeta.

68. Timmers, P. (1998) 'Business Models for Electronic Commerce', EM -Electronic Markets 8(2), pp. 3-8,

69. Teece, D. (2010), "Business models, business strategy and innovation", Long Range Planning, Vol. 43 Nos 2/3, pp. 172-194. Emerald Publishing.

70. Umar, H. 2005. Strategic Management In Action. PT. Gramedia Pustaka Utama, Jakarta.

71. Wolcott RC, Lippitz MJ. 2007. The four models of corporate entrepreneurship. MIT Sloan Management Review 49(1):75-82.

72. Woo, Ji Young, Bae, Sung Min, and Park, Sang Chan (2005). Visualization method for customer targeting using customer map. Expert Systems with Applications, 28, 763-772.

73. Willis, T.H. Vender Requirements and Evaluation in a Just-In-Time Environment. International Journal of Operations and Production Management 10(4), 41-50 (1990).

74. Williams, Chuck, 2001. Manajemen, Buku 1, Edisi Pertama, Alih Bahasa Sabarudin Napitupulu, Salemba Empat, Jakarta.

75. Wibisono, Dermawan, 2006. Maajemen Kinerja. Jakarta: Erlangga.

76. Zott C, Amit R. 2007. Business model design and the performance of entrepreneurial firms.Organization Science Journal, 18 (2): 181-199. 